\title{
Independent effects of jasmonates and ethylene on inhibition of Pharbitis nil flowering
}

\author{
Jacek Kęsy • Emilia Wilmowicz $\cdot$ Beata Maciejewska • \\ Kamil Frankowski $\cdot$ Paulina Glazińska • \\ Jan Kopcewicz
}

Received: 4 May 2010/Revised: 27 October 2010/Accepted: 16 November 2010/Published online: 4 December 2010

(C) The Author(s) 2010. This article is published with open access at Springerlink.com

\begin{abstract}
Interactions between methyl jasmonate (JA-Me) and ethylene in the photoperiodic flower induction of shortday plant Pharbitis nil were investigated. Both JA-Me and gaseous ethylene applied during the inductive long night caused a decrease in the number of flower buds generated by $P$. nil. Application of ethylene did not affected niether the level of endogenous jasmonates in the cotyledons during the $16 \mathrm{~h}$ long inductive night, nor the inhibitory effect of JA-Me on the flowering of $P$. nil accompanied by variations in ethylene production. The application of acetylsalicylic acid (aspirin)—a jasmonate biosynthesis inhibitor—slightly stimulated flowering. Our results have shown that the mechanisms of $P$. nil flower inhibition by jasmonates and ethylene are independent.
\end{abstract}

Keywords Methyl jasmonate · Ethylene - Flowering · Pharbitis nil (Ipomoea nil)

\section{Introduction}

The transition from the vegetative to the reproductive phase is one of the most critical developmental events during the life cycle of plants. This process is regulated by both endogenous and environmental factors. Although discoveries made in the recent years show that in photoperiod-sensitive plants the protein FT (Flowering Locus T)

Communicated by J. Ueda.

J. Kęsy · E. Wilmowicz $(\bowtie) \cdot$ B. Maciejewska .

K. Frankowski · P. Glazińska · J. Kopcewicz

Department of Physiology and Molecular Biology of Plants,

Institute of General and Molecular Biology, Nicolaus

Copernicus University, 9 Gagarina Street, 87-100 Torun, Poland

e-mail: emwil@umk.pl exerts a decisive effect on flower induction (Corbesier et al. 2007; Jaeger and Wigge 2007; Mathieu et al. 2007), many earlier and present studies indicate that flower induction may also be caused by phytohormones, among which the major role is played by gibberellins (Corbesier and Coupland 2005; Mutasa-Göttgens and Hedden 2009; Quesada et al. 2005). In some plants, on the other hand, phytohormones-particularly auxins and ethylene-may successfully inhibit flower induction caused by photoperiod (Kęsy et al. 2008; Kulikowska-Gulewska et al. 1995; Ogawa and Zeevaart 1967; Suge 1972; Wilmowicz et al. 2008). The same effect is caused by jasmonates, which was observed in, for example, Spirodela polyrrhiza (Krajnčič and Nemec 1995), Wolffia arrhiza (Krajnéié and Cencié 2000), Nicotiana tabacum and Chenopodium rubrum (Albrechtová and Ullmann 1994; Barendse et al. 1985). JA-Me applied both to the roots and cotyledons, or shoot apices before or during the $16 \mathrm{~h}$ long inductive night also inhibits flowering in the model short-day plant Pharbitis nil (Maciejewska and Kopcewicz 2002).

In our earlier papers, we showed that the inhibitory effect of auxins on the flowering of $P$. nil may occur through stimulating ethylene biosynthesis in the cells (Kęsy et al. 2008). It cannot be excluded that interactions with ethylene may also occur when flowering is inhibited by jasmonates. Interactions between these two phytohormones play an important role in regulating many physiological processes e.g., the sprouting of seeds (Nojavan-Asghari and Ishizawa 1998), plumular hook straightening (Ellis and Turner 2002), fruit ripening (Perez et al. 1997) and rubber production (Saniewski et al. 1998), as well as in plant defence responses (Lorenzo et al. 2003). Interactions between ethylene and jasmonates on the level of biosynthesis may be either synergistic or antagonistic. It has been shown that jasmonates may both simulate and inhibit ethylene 
biosynthesis by affecting the activity of ACC synthase and oxidase (Hudgins and Franceschi 2004; Kępczyńska et al. 2009; Saniewski et al. 1987). Ethylene regulates the activity of genes involved in both the JA biosynthesis (AOS, allene oxide synthase) and signal transduction (VSP, vegetative storage protein) (Abe et al. 2008). The purpose of this paper is to study interactions on the biosynthesis level between JA-Me and ethylene in regulating the flowering of P. nil.

\section{Materials and methods}

Plant material

Seeds of Pharbitis nil Chois cv. Violet (Marutane Seed Co., Kyoto, Japan) were soaked in concentrated sulphuric acid for $45 \mathrm{~min}$, washed under running tap water for $2 \mathrm{~h}$ and soaked for $24 \mathrm{~h}$ in water $\left(26 \pm 1^{\circ} \mathrm{C}\right)$. The swollen seeds were sown in pots (15 seeds in each pot) filled with vermiculite and sand (1:1). The pots were transferred to a growth chamber at $26 \pm 1{ }^{\circ} \mathrm{C}$ with continuous irradiance $\left(130 \mu \mathrm{mol} \mathrm{m}{ }^{-2} \mathrm{~s}^{-1}\right.$ cool white fluorescent tubes, Polam, Warsaw, Poland) for 5 days. Five-day-old seedlings were exposed to a $16 \mathrm{~h}$ long darkness. In some experiments, the seedlings were treated with diverse active substances during the dark period. All manipulations during the dark period were performed under dim green light. After the treatments, the plants were grown in a growth chamber under continuous light $\left(130 \mu \mathrm{mol} \mathrm{m} \mathrm{m}^{-2} \mathrm{~s}^{-1}\right.$ cool white fluorescent tubes) at $26 \pm 1^{\circ} \mathrm{C}$ for 14 days. The number of floral buds per plant and the percentage of plants exhibiting terminal flowering were then determined using a stereoscopic microscope. At least 15 plants were used in each treatment, and each experiment was repeated at least three times. Data are presented as mean \pm standard error (SE). Student's $t$ test was used to calculate the significant differences compared with the control (symbols used in the figures and tables are $* P<0.05, * * P<0.01$ ).

\section{Plant treatment}

The 5 days old seedlings were incubated in $0.05 \%$ Tween 20 with JA-Me (at a concentration of $1 \mathrm{mM}$ ) with the solution penetrating through the roots. The plants were taken out of the pots, rinsed with distilled water, measured and transferred to Erlenmeyer flasks with $0.05 \%$ Tween 20/JA-Me solution during the $16 \mathrm{~h}$ long inductive night. After incubation, the plants were taken out of the erlenmeyer flasks, rinsed with distilled water, measured and transferred back to the pots. The control plants were incubated in $0.05 \%$ Tween 20 solution without JA-Me.

In the experiments examining the effect of ethylene on the flowering of $P$. nil, ethylene at a concentration of
$100 \mu \mathrm{l}^{-1}$ was put into the container via a syringe with a septum from $8 \mathrm{~h}$ to the end of the inductive night. The application was repeated every $2 \mathrm{~h}$, with ventilation before each injection, until the end of the night. Control plants were put under a glass dome and were not treated with ethylene.

Aspirin at a concentration $1 \mathrm{mM}$ in $0.05 \%$ Tween 20 was applied on the cotyledons at the hours 6,8 , and 10 of the $16 \mathrm{~h}$ long inductive night. Control plants were treated with $0.05 \%$ Tween 20 solution without aspirin.

In experiments examining the influence of ethylene on jasmonates content, the pots with seedlings were enclosed in a 91 glass container. Ethylene at a concentration of $100 \mu \mathrm{l}^{-1}$ was put into the container via a syringe with a septum from the beginning of the night. The application was repeated every $2 \mathrm{~h}$, with ventilation before each injection, until the end of the night. Control plants were put under a glass dome and were not treated with ethylene. In order to determine the endogenous jasmonates content, cotyledons were picked at hours $2,4,6,8,10,12,14$ and 16 of the inductive night.

In the experiments examining the influence of aspirin on ethylene production, aspirin at a concentration of $1 \mathrm{mM}$ was applied on the cotyledons at hours 6,8 or 10 of the $16 \mathrm{~h}$ long inductive night. The control plants were treated with $0.05 \%$ Tween 20 solution without aspirin. The pots with 5 days old seedlings were enclosed in a 91 glass container. Ethylene production was measured $2 \mathrm{~h}$ after aspirin was applied i.e., at the hours 8,10 and 12 of the inductive night.

In the experiments examining the influence of JA-Me on ethylene production, the 5 days old plants were taken out of the pots, rinsed with distilled water, measured and transferred to erlenmeyer flasks with $0.05 \%$ Tween 20/JA-Me (at a concentration of $1 \mathrm{mM}$ ) during the $16 \mathrm{~h}$ long inductive dark period. The pots were enclosed in a of 91 glass container. The ethylene produced by the plants was measured at the hours 2, 4, 7, 10 and 13 of the inductive darkness, and at the hour 17 after its completion. The control plants were incubated in $0.05 \%$ Tween 20 solution. The data are means of three independent experiments \pm SE.

Determination of endogenous jasmonates and ethylene content

For jasmonates (JA + JA-Me) analyses, the methods of Gundlach et al. (1992) and Fan et al. (1998) with modifications were used. The plant material collection time is indicated in the descriptions of Fig. 3. P. nil cotyledons (2-3 g) were frozen in liquid $\mathrm{N}_{2}$ and homogenized in a chilled mortar with a pestle. Jasmonates was extracted with $90 \%(\mathrm{v} / \mathrm{v})$ methanol in two 
Table 1 The effect of JA-Me, aspirin and ethylene on the flowering of 5 days old Pharbitis nil seedlings

\begin{tabular}{lllll}
\hline & Control & JA-Me & Ethylene & Aspirin \\
\hline Number of flower buds \pm SE & $6.5 \pm 0.2$ & $2.8 \pm 0.3^{* *}$ & $0^{* *}$ & $7.3 \pm 0.1^{*}$ \\
Percentage of plants with terminal flower bud $(\%)$ & 100 & 8 & 0 & 100 \\
\hline
\end{tabular}

The plants were incubated with JA-Me $1 \mathrm{mM}$ during a $16 \mathrm{~h}$ long night. Ethylene at a concentration of $100 \mu \mathrm{l} / \mathrm{dm}^{3}$ was put into a container from the 8th hour to the end of the inductive night. Aspirin, at a concentration of $1 \mathrm{mM}$, was applied in 6th, 8th and 10th hour of the inductive night on the cotyledons. For more details on substances application see the "Materials and methods". 45 plants were used in the experiment (from three independent experiments with 15 replicates within each). Significant differences compared to the control are indicated as $* P<0.05, * * P<0.01$

parts of $40 \mathrm{ml}$ each. $\mathrm{d}_{2}$-JA-Me $750 \mathrm{ng}$ was added to the extract as an internal standard. The extract was reduced to the aqueous phase, acidified to $\mathrm{pH} 2$ with $12 \mathrm{M} \mathrm{HCl}$ and centrifuged at $12,000 \mathrm{~g}$ for $30 \mathrm{~min}$ to remove precipitated chlorophyll. The supernatant was partitioned three times against chloroform, and dried under vacuum. The pellet was dissolved in $3 \mathrm{ml} n$-hexane and applied to a silica gel solid-phase extraction column (Backer-bound SPE silica gel, $500 \mathrm{mg}, 3 \mathrm{ml}$; J.T. Backer, Philipsburg, NJ, USA). The column was washed with $5 \mathrm{ml} n$-hexane and then eluted with $5 \mathrm{ml}$ of $n$-hexane:diethyl ether, 2:1 $(\mathrm{v} / \mathrm{v})$ with $0.5 \% \quad(\mathrm{v} / \mathrm{v})$ acetic acid. The sample was evaporated to dryness, methylated with diazomethane, dissolved in $50 \mu \mathrm{l}$ of methanol and analyzed by GCMS-SIM (Auto-System XL coupled to a Turbo Mass, Perkin Elmer) using a DB-5 column $(30 \mathrm{~m} \times 0.25 \mathrm{~mm}$, $0.5 \mu \mathrm{m}$ phase thickness). The GC temperature programme was $80^{\circ} \mathrm{C}$ for $1 \mathrm{~min}, 80-160^{\circ} \mathrm{C}$ at $10^{\circ} \mathrm{C} \mathrm{min}{ }^{-1}$, $160-230^{\circ} \mathrm{C}$ at $5^{\circ} \mathrm{C} \mathrm{min}^{-1}$, flow rate $1 \mathrm{ml} \mathrm{min}{ }^{-1}$, injection port $250^{\circ} \mathrm{C}$, electron potential $70 \mathrm{eV}$. The retention times of JA-Me and $\mathrm{d}_{2}$-JA-Me were 11.37 and $11.34 \mathrm{~min}$, respectively. GC/MS-selected ion monitoring was performed by monitoring $\mathrm{m} / \mathrm{z} 156,158,224$ and 226. The dwell time for all ions was $100 \mathrm{~ms}$. The level of jasmonates in the extract was determined from the ratio of the peak area for $224 / 226$.

Ethylene production in seedlings was measured every $2 \mathrm{~h}$ during the $16 \mathrm{~h}$ long dark period by enclosing pots containing 15 plants for $30 \mathrm{~min}$ in 91 jars. After that time, $100 \mathrm{ml}$ of air was collected through the septa, after which ethylene from the sample was trapped for $5 \mathrm{~min}$ in $2 \mathrm{ml}$ of $0.25 \mathrm{M}$ mercuric perchlorate in $2 \mathrm{M}$ perchloric acid according to Abeles (1973). The trapping solution $(1.8 \mathrm{ml})$ was transferred to a $4.6 \mathrm{ml}$ vial and an equal volume of $4 \mathrm{M} \mathrm{LiCl}$ was added. The vial was tightly closed and shaken for $2 \mathrm{~min}$. The released ethylene was taken through the septa and determined by gas chromatography on an RTX-5 Q-PLOT column (RESTEK Corp., USA; $30 \mathrm{~m} \times 0.53 \mathrm{~mm}$ ID) at $40^{\circ} \mathrm{C}$, using a flame ionizing detector. Injector and detector temperatures were 60 and $105^{\circ} \mathrm{C}$, respectively.

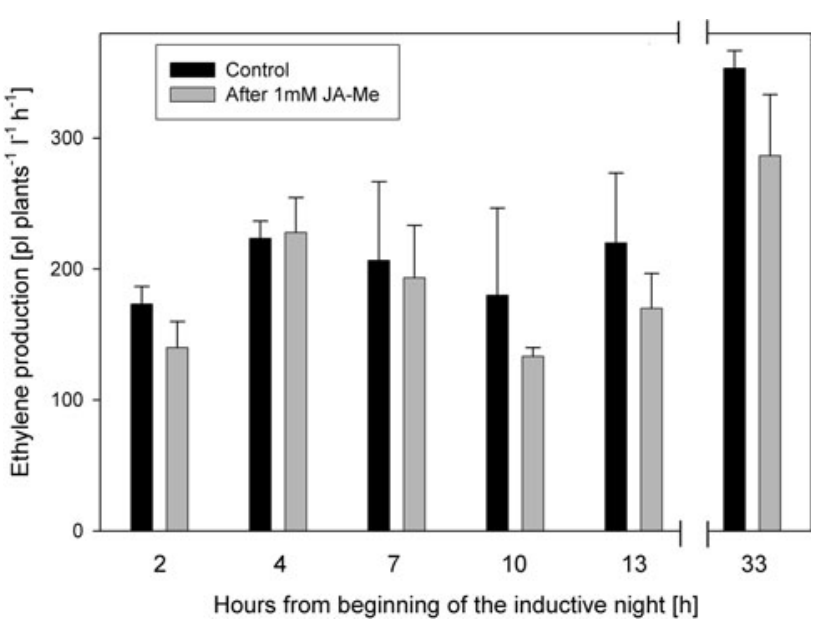

Fig. 1 Effect of JA-Me on ethylene production by 5 days old Pharbitis nil seedlings subjected to $16 \mathrm{~h}$ long inductive dark period. Plants were incubated with JA-Me at a concentration of $1 \mathrm{mM}$ in $0.05 \%$ Tween solution (grey bars) during a $16 \mathrm{~h}$ long night. Control plants (black bars) were incubated with $0.05 \%$ Tween solution. The data are the means of three independent experiments $\pm \mathrm{SE}$

\section{Results}

Five-day-old $P$. nil seedlings incubated with $1 \mathrm{mM}$ exogenous JA-Me during a $16 \mathrm{~h}$ long night formed about $50 \%$ fewer flower buds than control plants, while generative terminal buds were formed only in $8 \%$ of the plants (Table 1). The application of ethylene during a $16 \mathrm{~h}$ inductive night inhibited flowering completely, as none of the plants formed neither auxiliary nor terminal flower buds. On the other hand, plants treated with aspirin, a jasmonate biosynthesis inhibitor, formed one generative bud more than the control ones, and all of them had a terminal flower bud (Table 1).

The level of ethylene produced by the control seedlings was found to vary slightly during the inductive dark period and after its completion (from 173 to $220 \mathrm{pl} \mathrm{l}^{-1} \mathrm{~h}^{-1}$ plants $^{-1}$ ) (Fig. 1). Under the same conditions, plants put in a $1 \mathrm{mMJA}-$ Me solution produced a similar-or slightly lower-amount of ethylene, however the differences were not statistically significant. Aspirin, applied on the cotyledons of 


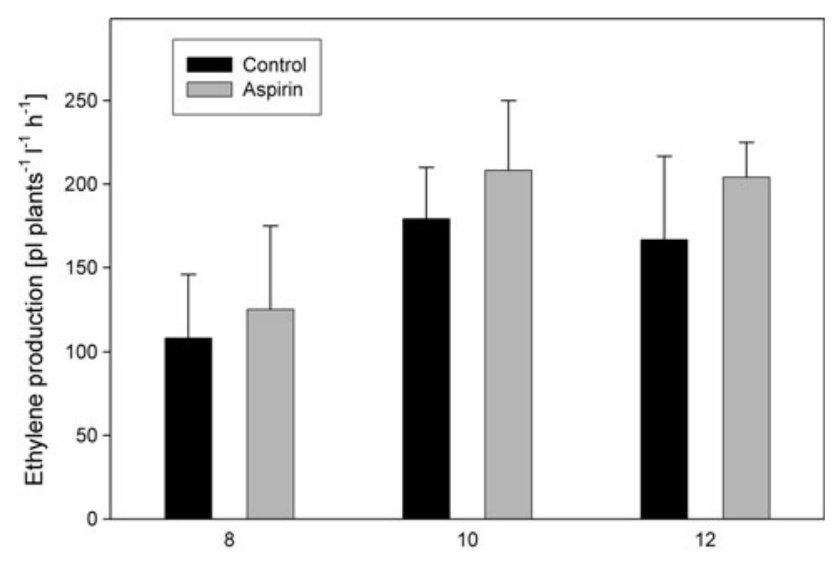

Hours from beginning of the inductive night [h]

Fig. 2 Effect of aspirin on ethylene production by 5 days old Pharbitis nil seedlings subjected to $16 \mathrm{~h}$ long inductive dark period. Aspirin was applied at a concentration of $1 \mathrm{mM}$ in $0.05 \%$ Tween solution on the cotyledons (grey bars) on 6th, 8th and 10th hour of a $16 \mathrm{~h}$ long dark period. The control plants (black bars) were treated with $0.05 \%$ Tween solution. The data are means of three independent experiments (with 15 plants in each) $\pm \mathrm{SE}$

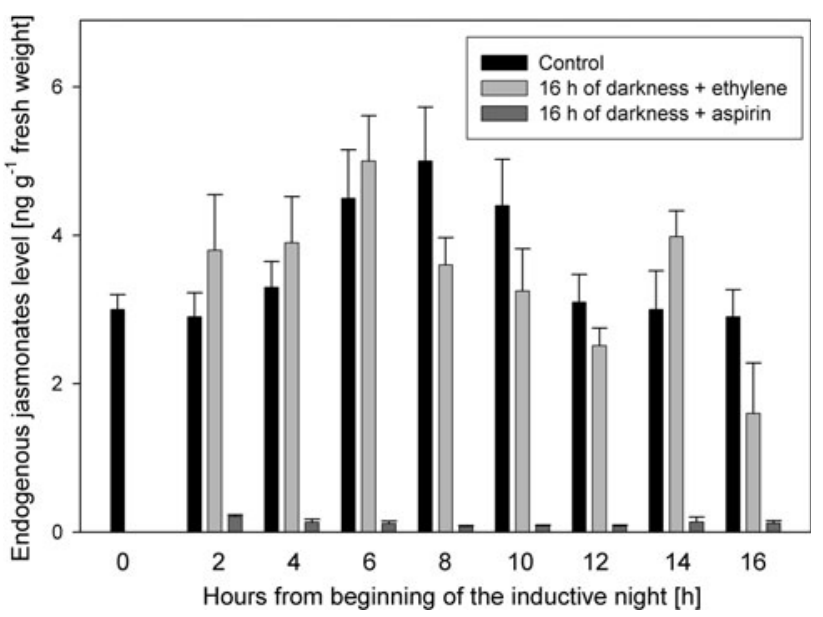

Fig. 3 Changes in jasmonates (JA + JA-Me) content $\left(\mathrm{ng} \mathrm{g}^{-1}\right.$ fresh weight) in cotyledons of 5 days old Pharbitis nil during the inductive photoperiod (16 h of darkness-black bars) and caused by ethylene (grey bars) and aspirin treatment (dark gray bars). Aspirin was applied at a concentration of $1 \mathrm{mM}$ in $0.05 \%$ Tween solution on the cotyledons in 0th hour of a $16 \mathrm{~h}$ long dark period. For details on ethylene application, see the "Materials and methods". Values are the means of three separate samples with two replications for each sample

$P$. nil seedlings, caused a slight increase in ethylene production (Fig. 2), bud results were also not statistically significant.

As shown in Fig. 3 application of $1 \mathrm{mM}$ aspirin into cotyledons at the beginning of the inductive night resulted in a clear decrease of jasmonates level. The content of endogenous jasmonates (JA + JA-Me) in the cotyledons of $P$. nil seedlings treated with ethylene during the inductive night is comparable to the content found in the cotyledons of the control plants (Fig. 3), first being a little lower, and then - at the end of the night - a little higher than in the control plants. These differences are statistically significant only at 8 th, 10th and 16 th $\mathrm{h}$ during the inductive night.

\section{Discussion}

Interactions between jasmonates and ethylene in $P$. nil seedlings' flower induction were investigated by determining their mutual effect on biosynthesis and flowering in response to aspirin, which was shown to inhibit JA formation and the JA-induced expression of defence-related genes in tomato (Pena-Cortes et al. 1993; Doares et al. 1995). Salicylates were shown to be competitive inhibitors of allene oxide synthase, a vital enzyme for JA biosynthesis (Pan et al. 1998). The use of a biosynthesis inhibitor was the only method available for reducing the jasmonate content in $P$. nil's tissues, due to a lack of relevant mutants and because of the difficulties in obtaining transformed plants. The results presented in Table 1 show that applying aspirin leads to decrease in JA level and a certain degree of flowering stimulation, which-with no accompanying effect on the production of ethylene (Fig. 2), a strong inhibitor of flowering in $P$. nil (Table 1)-suggests that endogenous JA-Me in the cotyledons of $P$. nil may function as an inhibitor of flowering. The data indicating jasmonates' effects on inhibition of flowering in SDP were previously presented by Albrechtová and Ullmann (1994), Barendse et al. (1985), Maciejewska and Kopcewicz (2002), Maciejewska et al. (2004).

Jasmonates have been reported to both stimulate and inhibit ethylene production in many plants such as tomato, Arabidopsis, and tobacco (e.g., O’Donnell et al. 1996; Penninckx et al. 1998; Xu et al. 1994), although there have been no such reports in the context of photoperiodic flower induction.

Our studies showed only an insignificant effect of jasmonates on ethylene production in Pharbitis nil seedlings (Fig. 1). Seedlings subjected to flower induction and simultaneously treated with $1 \mathrm{mM}$ JA-Me generated an amount of ethylene comparable to that produced by the control plants. This clearly suggests that the inhibitory effect of exogenous jasmonates on flower induction in $P$. nil does not result from the stimulation of ethylene production, in contrast to what was the case for auxins (Kęsy et al. 2008). Experiments made on SDP Chenopodium rubrum also showed that JA-Me inhibited flowering, without exerting any effect on ethylene production (Albrechtová and Ullmann 1994).

We have shown that application of ethylene during the inductive night similarly did not exert a significant effect on the level of jasmonates in the cotyledons of $P$. nil seedlings (Fig. 3). This indicates that the mechanism of 
flower inhibition by jasmonates is independent. Independent action of both hormones in the regulation of other physiological processes is observed also in forming the abscission zone in bean explants (Ueda et al. 1996).

Our earlier research showed that abscisic acid may play a vital role in ethylene's inhibitory effect on flowering (Wilmowicz et al. 2008). It has not yet been excluded that a similar interaction takes place between $\mathrm{ABA}$ and jasmonates.

Within the last decade great progress has been made in discovering the biosynthesis and phytohormone signal transduction pathways (Santner and Estelle 2009). This has helped to reveal the mechanisms of numerous interactions between these substances in regulating various growth and developmental phenomena.

Our results have shown that inhibitory effects of JA-Me and ethylene on flowering are independent. However, in order to make an exact determination of interactions between ethylene and jasmonates in flower induction, additional research into the effect of these substances on the expression of genes related to their biosynthesis and signal transduction is needed.

Acknowledgments This research was partially supported by the Polish Ministry of Science and Higher Education grant N 303321637.

Open Access This article is distributed under the terms of the Creative Commons Attribution Noncommercial License which permits any noncommercial use, distribution, and reproduction in any medium, provided the original author(s) and source are credited.

\section{References}

Abe H, Ohnishi J, Narusaka M, Seo S, Narusaka Y, Tsuda S, Kobayashi M (2008) Function of jasmonate in response and tolerance of Arabidopsis to thrip feeding. Plant Cell Physiol 49:68-80

Abeles FB (1973) Ethylene in plant biology. Academic Press, New York, London, pp 10-29

Albrechtová JTP, Ullmann J (1994) Methyl jasmonate inhibits growth and flowering in Chenopodium rubrum. Biol Plant 36:317-319

Barendse GWM, Croes AF, Van den Ende G, Bosveld M, Creemers T (1985) Role of hormones on flower bud formation in thin-layer explants of tobacco. Biol Plant 27:408-412

Corbesier L, Coupland G (2005) Photoperiodic flowering of Arabidopsis: integrating genetic and physiological approaches to characterization of the floral stimulus. Plant Cell Environ 28:54-66

Corbesier L, Vincent C, Jang S, Fornara F, Fan Q, Searle I, Giakountis A, Farrona S, Gissot L, Turnbull C, Coupland G (2007) FT protein movement contributes to long-distance signaling in floral induction of Arabidopsis. Science 316: $1030-1033$

Doares SH, Narvaez-Vasquez J, Conconi A, Ryan CA (1995) Salicylic acid inhibits synthesis of proteinase inhibitors in tomato leaves induced by systemin and jasmonic acid. Plant Physiol 108:1741-1746
Ellis C, Turner JG (2002) A conditionally fertile coil allele indicates cross-talk between plant hormone signalling pathways in Arabisopsis thaliana seeds and young seedlings. Planta 215:549-556

Fan X, Mattheis JP, Fellman JK (1998) A role for jasmonates in climacteric fruit ripening. Planta 204:444-449

Gundlach H, Müller MJ, Kutchan TM, Zenk MH (1992) Jasmonic acid is a signal transducer in elicitor-induced plant cell cultures. Proc Natl Acad Sci USA 89:2389-2393

Hudgins JW, Franceschi VR (2004) Methyl jasmonate-induced ethylene production is responsible for conifer phloem defense responses and reprogramming of stem cambial zone for traumatic resin duct formation. Plant Physiol 13:2134-2149

Jaeger KE, Wigge PA (2007) FT protein acts as a long-range signal in Arabidopsis. Curr Biol 17:1050-1054

Kępczyńska E, Ruduś I, Kępczyński J (2009) Abscisic acid and methyl jasmonate as regulators of ethylene biosynthesis during somatic embryogenesis of Medicago sativa L. Acta Physiol Plant $31: 1263-1270$

Kęsy J, Maciejewska B, Sowa M, Szumilak M, Kawałowski K, Borzuchowska M, Kopcewicz J (2008) Ethylene and IAA interactions in the inhibition of photoperiodic flower induction of Pharbitis nil. Plant Growth Regul 55:43-50

Krajnčič B, Nemec J (1995) The effect of jasmonic acid on flowering in Spirodela polyrrhiza (L.) Schleiden. J Plant Physiol 146:754-756

Krajnéié B, Cencié A (2000) The effect of jasmonic acid on flowering in the long-short-day plant Wolffia arrhiza (L.) Horkel ex Wimm. Plant Physiol Biochem Suppl 38:40

Kulikowska-Gulewska H, Cymerski M, Czaplewska J, Kopcewicz J (1995) IAA in the control of photoperiodic flower induction of Pharbitis nil Chois. Acta Soc Bot Polon 64:45-50

Lorenzo P, Piqueras R, Sanchez-Serrano JJ, Solano R (2003) ETHYLENE RESPONSE FACTOR1 integrates signals from ethylene and jasmonate pathways in plant defense. Plant Cell 15:165-179

Maciejewska B, Kopcewicz J (2002) Inhibitory effect of methyl jasmonate on flowering and elongation growth in Pharbitis nil. J Plant Growth Regul 21:216-223

Maciejewska BD, Kęsy J, Zielińska M, Kopcewicz J (2004) Jasmonates inhibit flowering in short-day plant Pharbitis nil. Plant Growth Regul 43:1-8

Mathieu J, Warthmann N, Kuttner F, Schmid M (2007) Export of FT protein from phloem companion cells is sufficient for floral induction in Arabidopsis. Curr Biol 17:1055-1060

Mutasa-Göttgens E, Hedden P (2009) Gibberellin as a factor in floral regulatory networks. J Exp Bot 60:1979-1989

Nojavan-Asghari M, Ishizawa K (1998) Inhibitory effects of methyl jasmonate on the germination and ethylene production in cocklebur seeds. J Plant Growth Regul 17:13-18

O’Donnell PJ, Calvert C, Atzorn R, Wasternack C, Leyser HMO, Bowles DJ (1996) Ethylene as a signal mediating the wound response of tomato plants. Science 274:1914-1917

Ogawa Y, Zeevaart JAD (1967) The relation of growth regulators to flowering: auxin. In: Imamura S (ed) Physiology of flowering in Pharbitis nil. Japanese Society of Plant Physiologists, Kyoto, pp 107-108

Pan ZQ, Camara B, Gardner HW, Backhaus RA (1998) Aspirin inhibition and acetylation of the plant cytochrome P450, allene oxide synthase, resembles that of animal prostaglandin endoperoxide H synthase. J Biol Chem 273:18139-18145

Pena-Cortes H, Albrecht T, Prat S, Weiler EW, Willmitzer L (1993) Aspirin prevents wound-induced gene expression in tomato leaves by blocking jasmonic acid biosynthesis. Planta 191: $123-128$

Penninckx IAMA, Thomma BPHJ, Buchala A, Metraux JP, Broekaert WF (1998) Concomitant activation of jasmonate and ethylene 
response pathways is required for induction of a plant defensin gene in Arabidopsis. Plant Cell 10:2103-2113

Perez AG, Sanz C, Olias R, Olias JM (1997) Effect of methyl jasmonate on in vitro strawberry ripening. J Agric Food Chem 45:3733-3737

Quesada V, Dean C, Simpson GG (2005) Regulated RNA processing in the control of Arabidopsis flowering. Int J Dev Biol 49: 773-780

Saniewski M, Czapski J, Nowacki J (1987) Relationship between stimulatory effect of methyl jasmonate on ethylene and 1-aminocyclopropane-1-carboxylic acid content in tomatoes. Biol Plant 29:17-21

Saniewski M, Miyamoto K, Ueda J (1998) Gum formation by methyl jasmonate in tulip shoots is stimulated by ethylene. J Plant Growth Regul 17:179-183

Santner A, Estelle M (2009) Recent advances and emerging trends in plant hormone signaling. Nature 459:1071-1078
Suge H (1972) Inhibition of photoperiodic floral induction in Pharbitis nil. Plant Cell Physiol 13:1031-1038

Ueda J, Miyamoto K, Hashimoto M (1996) Jasmonates promote abscission in bean petiole explants: its relationship to the metabolism of cell wall polysaccharides and cellulase activity. J Plant Growth Regul 15:189-195

Wilmowicz E, Kęsy J, Kopcewicz J (2008) Ethylene and ABA interactions in the regulation of flower induction in Pharbitis nil. J Plant Physiol 165:1917-1928

$\mathrm{Xu} \mathrm{Y,} \mathrm{Chang} \mathrm{PF,} \mathrm{Liu} \mathrm{D,} \mathrm{Narasimhan} \mathrm{ML,} \mathrm{Raghothama} \mathrm{KG,}$ Hasegawa PM, Bressan RA (1994) Plant defense genes are synergically induced by ethylene and methyl jasmonate. Plant Cell 6:1077-1085 